
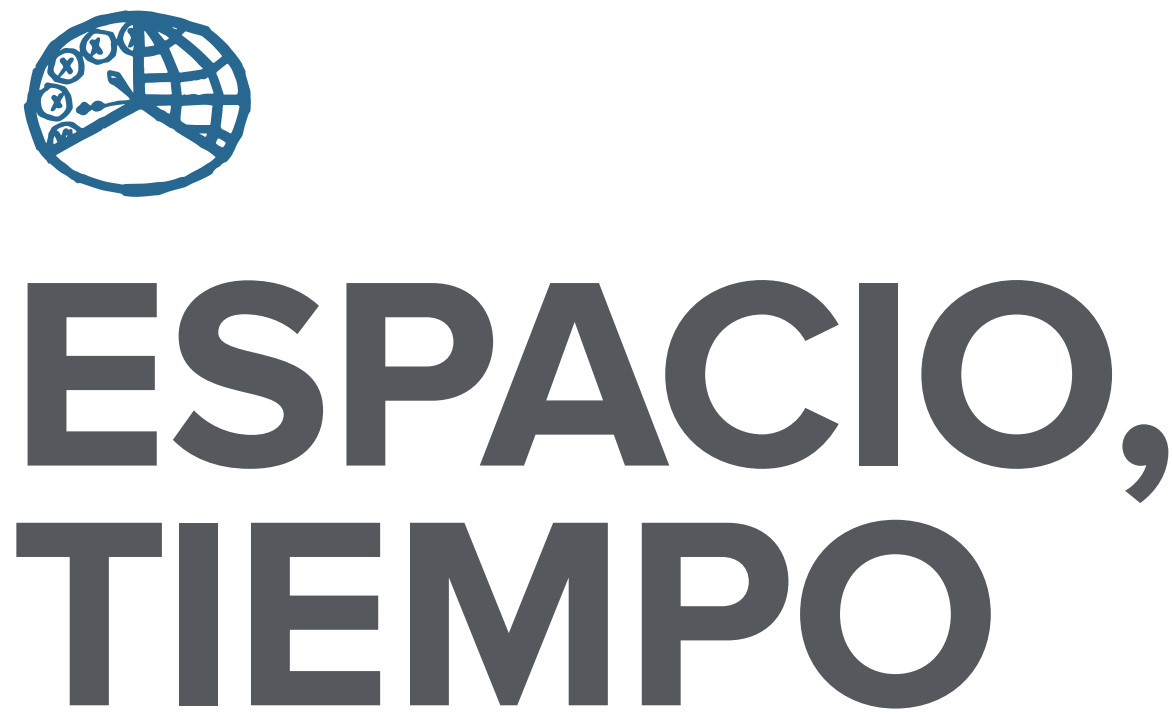

AÑO 2016

NUEVA ÉPOCA

ISSN 1130-4715

E-ISSN 2340-1478
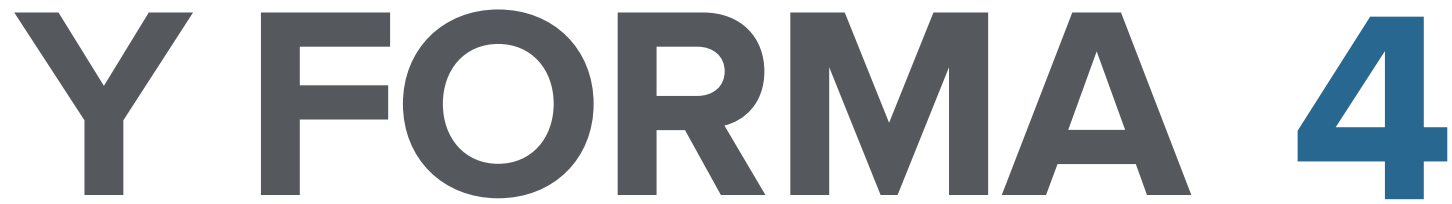

SERIE VII HISTORIA DEL ARTE

REVISTA DE LA FACULTAD DE GEOGRAFÍA E HISTORIA 

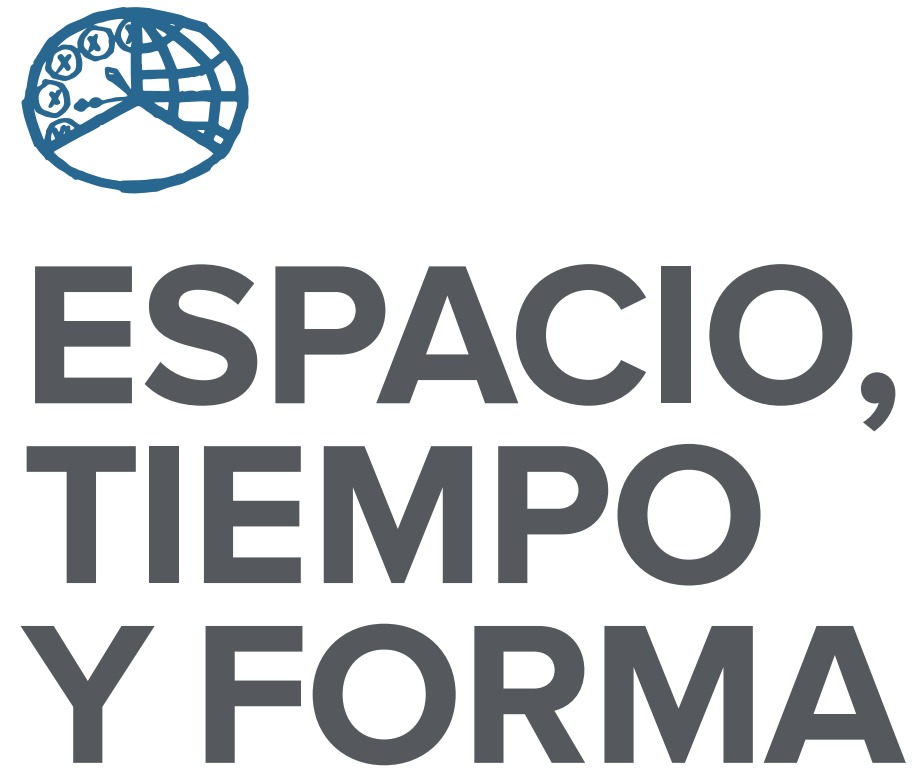

AÑO 2016

NUEVA ÉPOCA

ISSN $1130-4715$

E-ISSN 2340-1478

SERIE VII HISTORIA DEL ARTE

REVISTA DE LA FACULTAD DE GEOGRAFÍA E HISTORIA

DOI: http://dx.doi.org/10.5944/etfvii.4.2016

\section{UกED}

UNIVERSIDAD NACIONAL DE EDUCACIÓN A DISTANCIA 
La revista Espacio, Tiempo y Forma (siglas recomendadas: ETF), de la Facultad de Geografía e Historia de la UNED, que inició su publicación el año 1988, está organizada de la siguiente forma:

$$
\begin{aligned}
& \text { SERIE I - Prehistoria y Arqueología } \\
& \text { SERIE II - Historia Antigua } \\
& \text { SERIE III - Historia Medieval } \\
& \text { SERIE IV - Historia Moderna } \\
& \text { SERIE V - Historia Contemporánea } \\
& \text { SERIE VI - Geografía } \\
& \text { SERIE VII - Historia del Arte }
\end{aligned}
$$

Excepcionalmente, algunos volúmenes del año 1988 atienden a la siguiente numeración:

$$
\begin{aligned}
& \mathrm{N}^{\circ} 1 \text { - Historia Contemporánea } \\
& \mathrm{N}^{\circ} 2 \text { - Historia del Arte } \\
& \mathrm{N}^{\circ} 3 \text { - Geografía } \\
& \mathrm{N} .^{\circ} 4 \text { - Historia Moderna }
\end{aligned}
$$

ETF no se solidariza necesariamente con las opiniones expresadas por los autores.

\author{
UNIVERSIDAD NACIONAL DE EDUCACIÓN A DISTANCIA \\ Madrid, 2016 \\ SERIE VII · HISTORIA DEL ARTE (NUEVA ÉPOCA) N. ${ }^{\circ} 4,2016$ \\ ISSN $1130-4715 \cdot$ E-ISSN 2340-1478 \\ DEPÓSITO LEGAL \\ $M-21.037-1988$ \\ URL \\ ETF VII · HISTORIA DEL ARTE · http://revistas.uned.es/index.php/ETFVII \\ DISEÑO Y COMPOSICIÓN \\ Carmen Chincoa Gallardo · http:/www.laurisilva.net \\ Impreso en España · Printed in Spain
}

(c) (1) (8) Esta obra está bajo una licencia Creative Commons Reconocimiento-NoComercial 4.0 Internacional. 


\section{DOSSIER}

ART MOVES:

PERFORMATIVITY IN TIME, SPACE AND FORM

by Mieke Bal

EL ARTE (SE) MUEVE:

PERFORMATIVIDAD EN EL TIEMPO, EL ESPACIO Y LA FORMA

por Mieke Bal 



\section{DOSSIER}

FIRST REFLECTIONS ON MOVEMENT 


\title{
DESPLAZAMIENTOS (IN)MÓVILES
}

\section{(IM)MOBILE DISPLACEMENTS}

\author{
Mar García Ranedo ${ }^{1}$ \\ Recibido: 31/10/2015 - Aceptado: 25/02/2016 \\ DoI: http://dx.doi.org/10.5944/etfvii.4.2016.15529
}

\section{Resumen}

Proponemos un acercamiento, analítico y comparativo, al movimiento desde una serie de obras organizadas como secuencias visuales que argumentan la sintaxis de la representación a partir del empleo de la imagen fotográfica, el dibujo y la palabra. Por un lado, en las fotosecuencias, el movimiento no sólo aparece como inscripción de un recorrido físico, recogido a través de una fluencia de imágenes fotográficas, o por la acción de capturar e ir tras el objetivo, sino también como un trayecto ideológico organizado a través del orden semiótico de la propia imagen fotográfica y del encuadre como estructurador de la mirada. Por otro lado, en el pictograma dibujado, el movimiento es iniciado por el propio acto de marcar y manchar el papel. El dibujo es interpretado como una acción que establece relaciones escénicas y temporales tanto con el espacio real y físico como con la psique. Las obras que han motivado este análisis, tituladas Affidamento, La imagen negada, Posiciones y Correspondencias, persiguen poner en pie una gramática dinámica de la representación.

\section{Palabras clave}

Movimiento; Duración; Fotografía; Encuadre; Pictograma; Pelo; Dibujo; Mirada.

\section{Abstract}

With this article I propose an analytical and comparative approach to movement based on a series of works organised as visual sequences which argue for the syntax of representation using the photographic image, drawing and words. On the one hand, in the sequences of photos, movement does not only appear as an inscription of a physical route, recorded by a fluency of photography images or by the action of capturing and pursuing the objective, but also as an ideological trajectory organised through the semiotic order of the photographic image itself and of the framing as the element that structures the gaze. And on the other hand, in the drawn pictogram, movement is initiated by the very act of marking and staining the paper. Drawing is interpreted as an action that establishes scenic and temporary relations both

1. Universidad de Sevilla (ranedomar@gmail.com). 
with the real, physical space and with the psyche. The works that motivated this analysis, entitled, Affidamento, Posiciones, La imagen negada and Correspondencias, aim to establish a dynamic grammar of representation.

Keywords

Movement; Duration; Photography; Framing; Pictogram; Hair; Drawing; Gaze. 


\section{LA PARÁLISIS MÓVIL DE LA IMAGEN}

«Ninguna imagen reemplazará la intuición de la duración, pero muchas imágenes, tomadas de órdenes de cosas muy distintas, podrán, por convergencia de su acción, dirigir la conciencia al punto preciso donde se hace palpable una cierta intuición». ${ }^{2}$

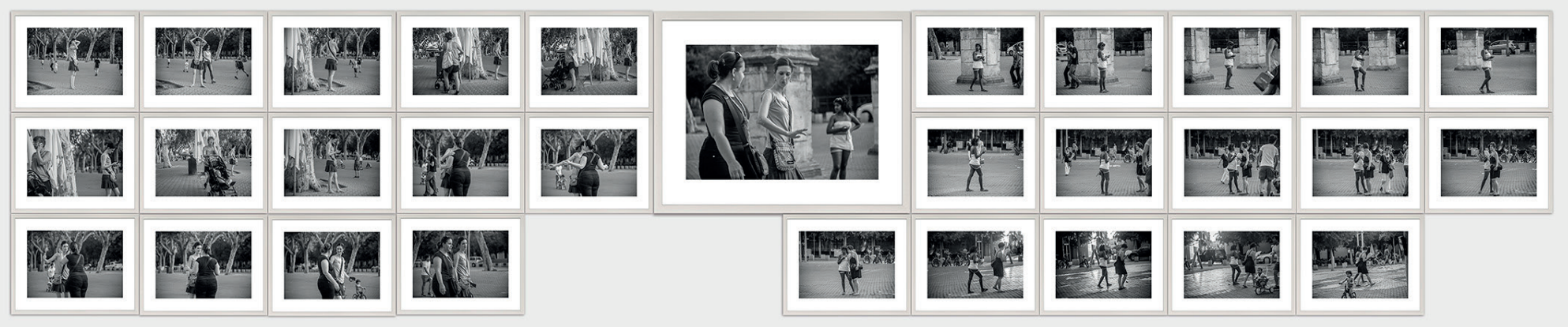

FIGURA 1. AFFIDAMENTO, 29 IMÁGENES DE 60 × 60 CM Y I IMAGEN DE 60 x 80 cM. (C) margarciaranedo.

Que las fotografías sean consideradas inmóviles es relativo dado que obvia la interpretación cultural sujeta al encuentro con su historia. El momento decisivo, la detención del tiempo y la congelación de una acción son el fruto de una mirada que ha aislado un fragmento o porción de tiempo captado por el obturador y la luz. De manera que la interpretación de la inmovilidad de la fotografía, su fijación, no es otra cosa que un tiempo contenido a partir de una determinada mirada. Lo cierto es que desde que ese instante queda congelado, lejos de haber una amovilidad significante, lo que comienza es una conmixtión de elementos significadores. Una vez se demuestra que la fotografía, desde el momento que encuadra, es subjetiva, ésta pierde verismo. En el momento en que pierde verismo sus posibilidades de desplazamiento narrativo son tantas como la imaginación y cierta prudencia argumentativa son capaces de computar. A la interpretación de «inmovilidad» o de estatismo de la fotografía también podría añadirse la mudez. Paradójicamente, el significado de la imagen fotográfica se construye utilizando los mismos códigos del cine o la publicidad. El movimiento de las imágenes es el atributo esencial y específico del cine; la imagen fílmica se sustancia por dinamismo. Ahora bien, la fotografía no es esencialmente muda, y menos aún en los usos contemporáneos de la imagen donde ésta se acompaña de ruido mediático y audios empáticos programables.

Señala Bachelard, siguiendo la estela de Roupnel, que «el tiempo es una realidad afianzada en el instante y suspendida entre dos nadas». ${ }^{3}$ El instante y la duración son términos que se acercan al concepto tiempo desde dos posiciones. Por un lado, encontramos a Roupnel y su concepción del tiempo como un conjunto de instantes discontinuos e independientes entre sí. Por otra parte, Bergson interpreta

2. Bergson, Henri: Introducción a la metafísica y la intuición filosófica. Buenos Aires, Ediciones Siglo Veinte, $1966,24$.

3. BACHelard, Gastón: La intuición del instante. México, Fondo de Cultura Económica, 1999, 17-19. 

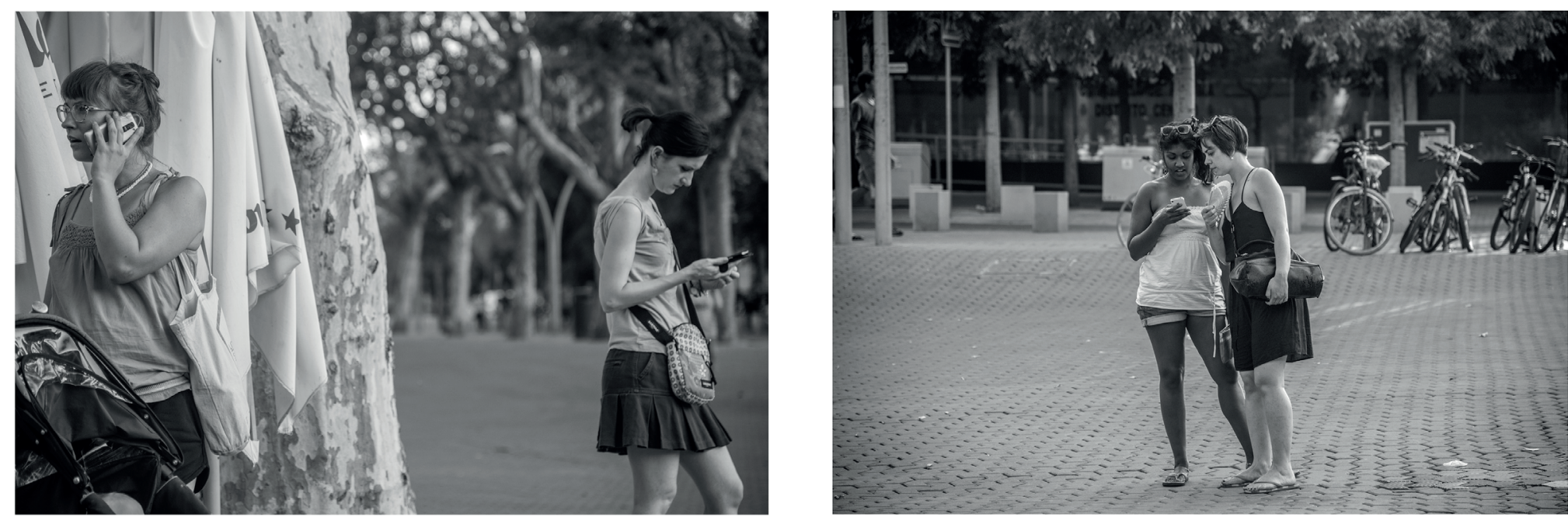

FIGURA 2 Y 3. AFFIDAMENTO (FRAGMENTO).

la duración como un simple agregado de momentos absolutos e indivisibles, un concepto que nos remite a un continuo progresar. Nos advierte acerca de la imposibilidad de representar mediante imágenes nuestra duración, es decir, el fluir de nuestra propia vida. A lo sumo, Bergson sugiere que podemos, mediante un esfuerzo imaginativo, solidificar la duración en una suma de trozos y que esta suma compondría el recuerdo congelado de la duración. ${ }^{4}$ ¿Es el movimiento el esquema espacio-temporal exacto de una serie de capturas o requiere de perspectiva fílmica? Representar el tiempo desde lo fotográfico y buscar el modo en que la duración quede fijada en la imagen es, en cierto modo, el intento de hacer visible todos esos instantes de realidad. Es, también, aproximar la imagen fotográfica a cierta experiencia de lo fílmico con la particularidad de que ésta, al ser una imagen fija o la suma de muchas de ellas, se mantiene en el terreno de la fantasía, alejada de la ilusión y de la función imitativa características del cine. El instante es el único testigo que puede dar veracidad a la realidad, es el detalle, la anécdota, el drama. La fotografía es, al mismo tiempo, instante, dado que certifica una muerte, una existencia pasada. Es el testimonio, el registro del «esto-ha-sido», la prueba de un momento muerto, congelado. Es el indicio de una actuación, en este sentido, no sólo es entendida como imagen sino también como acto. 5 Por otra parte, la duración es la memoria del momento; es la lectura detallada de trozos, de los fragmentos de existencia. La secuencialidad nos ayuda a conceptualizar el tiempo en una fotografía. La fotosecuencia, como estrategia proyectual, nos sugiere la representación virtual del tiempo, al promover un lapso, una acción que queda manifiesta en un desarrollo de secuencias. Es decir, podemos prever qué acontecerá después de un instante y qué le precedió. La fotosecuencia también nos introduce en el movimiento y, por tanto, en el desarrollo de una conclusión.

4. Bergson, Henri: Op. Cit. 30-31.

5. BARThes, Roland: La cámara lúcida. Madrid, Paidós, 2010, 90-92. 
En la obra titulada Affidamento, compuesta por treinta fotografías, una cita concertada entre dos personas da lugar a un emplazamiento y de ahí a un encuentro de nuevas citas y emplazamientos fortuitos que podrían ser explicados como concomitantes. Dentro del continuum sometemos a la observación y a la mirada, un espacio temporal limitado. El resultado visual es una fotosecuencia, que, entre otras cosas, sugiere un desplazamiento o movimiento a través de un flujo de imágenes. En esta fluencia de imágenes fotográficas, lo esencial no es aquello que se enfoca sino lo que propone y proyecta el objeto o sujeto seleccionado para su enfoque. En estas fotografías, lo interesante no es la representación del sujeto como objeto metafísico sino todas las posibilidades interpretativas que el sujeto genera con otros sujetos o elementos incluidos en el encuadre. Los sujetos o personas que aparecen e intervienen como actuantes dentro de un campo de acción determinado son puntos de enlace dentro de un escenario de posibilidades cruzadas. Las imágenes, por tanto, no se centran en lo constatable, en lo que dejan ver en el momento presente, sino en lo que sugieren, es decir, en las múltiples historias que pueden llegar a suceder y que están fuera del alcance de la mirada. La yuxtaposición de todos los fragmentos «completa» una historia inacabada. Al mismo tiempo, la continuidad de elementos define una unidad moviente y nos hace penetrar en una narrativa que nos aproxima a lo cinematográfico, que nos recuerda un film still.

Las series de fotografías tituladas: Affidamento, La imagen negada y Posiciones, procuran cierta inscripción del movimiento. Desde una lectura bergsoniana, estas series son el recuerdo, la impresión, la huella inmóvil que la movilidad de la duración ha dejado como memoria de un tiempo transcurrido, acontecido. Son imágenes que engloban tanto desplazamiento como espacio recorrido en una fracción de tiempo. Son fotografías en las que décimas de segundos han sido detenidas, congeladas del flujo de tiempo vital para visibilizar una franja, un momento concreto, una suma de instantes. Dar visibilidad a la duración, a través de la imagen fotográfica, es, por tanto, situarnos en lo concreto. Cada fotografía o «corte» visibiliza determinada posición en el espacio, a la vez que da forma concreta a determinado instante en el tiempo. ¿Puede la suma, la sucesión de todas esas posiciones e instantes reconstruir el movimiento? En un principio, Bergson consideró imposible reconstruir el movimiento con posiciones recorridas e instantes capturados. En tesis posteriores, Bergson analizaría cómo la ilusión cinematográfica era posibilitada a partir de una idea de movimiento construida con «cortes» o fotogramas. El cine, mediante un mecanismo de arrastre de imágenes, genera la idea de movimiento, pero no es un movimiento lineal sino la ilusión de esa percepción. Esas imágenes-movimiento, apunta Deleuze, encuentran su génesis en la fotografía instantánea. Diríamos, por tanto, que el cine reproduce el movimiento a partir de una serie de imágenes fijas y equidistantes, que consiguen, de este modo, la impresión de flujo y continuidad. ${ }^{6}$ En las series fotosecuenciales, antes mencionadas, el acontecimiento temporal recuerda al montaje fílmico, dado que organiza el armazón y el flujo de

\footnotetext{
6. Deleuze, Guilles: La imagen-movimiento. Estudios sobre cine 1. Barcelona, Buenos Aires, México, Paidós, 2013,
} 18-19. 
los fragmentos e instantes, se introduce en ellos y genera la ilusión de un acto o acción. José Luis Brea señala la importancia de la diferencia-mínima «de un veinticuatroavo de segundo exactamente, en la máquina cine» en el montaje de la secuencia de la imagen fílmica para emular de forma espontánea e «idéntica» un flujo de cambio que nos recuerde al acontecer o devenir del tiempo real. En estas series fotográficas la diferencia-mínima es un microtiempo entre capturas que separa el instante precedente del siguiente como un testigo de lo permanente. Todo lo que ocurre, por ejemplo, a las 5:01, 5:02, 5:03 será siempre señalado como una imagen fija e inmóvil, será la memoria de un instante concreto. Sin embargo, la imagen fílmica, fugaz y efímera, aprovecha la persistencia retiniana (veinticuatro imágenes por segundo) para que nuestro cerebro haga una lectura continua de movimiento. ${ }^{7}$ Las series fotográficas analizadas, los cortes inmóviles, los instantes equidistantes y la fluencia de la fotosecuencia pretenden poner en pie cierta aproximación del desplazamiento y la duración.

Capturar la duración y analizar determinados instantes es dar visibilidad al mundo, a personas anónimas, a sus necesidades de relacionarse, de comunicarse, es decir, a mostrar la apariencia de la vida. En cierto modo, una fotografía se significa por lo que recoge en la imagen al mismo tiempo que por lo que deja escapar fuera del encuadre. La persona que fotografía entra en un juego dialéctico con la realidad. Duane Michals decía, aludiendo a la máxima de Cartier Bresson, que en lugar de fotografiar el instante decisivo, él prefería capturar el momento anterior y el posterior ${ }^{8}$. El fotógrafo propone una elección, una posible puesta en escena de la duración, dado que lo real es aquello que se señala como tal, aquello que, por alguna razón, está en mí. En este sentido, la fotografía deja de ser análoga o «real literal» para ahondar en la imaginación'. La realidad no es lo que observamos en las fotografías, lo que éstas muestran es aquello que queremos que se vea, por tanto, es una interpretación que participa de cierta realidad. Desde esta aseveración, la fotografía no es capturada sino hecha y el fotógrafo no recoge lo que ve sino que propone como imagen lo que imagina. Por otra parte, habría que tener en cuenta la mirada del espectador. La forma en que éste mira y el modo en que recorre las imágenes espacialmente provocan una mutación en la lectura de la fotosecuencia dado que el sujeto receptor participa en ella procurándole un sentido diegético. La mirada es la alteración en la lectura horizontal, es la desarticulación de la linealidad y del orden que establece la fotosecuencia.

La serie fotográfica titulada Affidamento reproduce, en un movimiento de perseverancia y de espera, el encuentro, el meet-in, es decir, el estar dentro de la comunicación. La espera sorprende con el encuentro. Los sujetos se trasladan desde el

7. El autor señala que las imágenes-tiempo son aquellas que por su efimeridad no generan un vínculo de continuidad entre las imágenes subsecuentes, por lo que no son buenas para invocar memoria de origen y las considera imágenes del acontecer como tal, denominándolas imágenes-acontecimiento. BREA, José Luis: Las tres eras de la imagen. Madrid, Akal Estudios Visuales, 2010.

8. Soulages transcribe la entrevista, no publicada, que le hicieron a Duane Michals para France-Culture en noviembre de 1980 en SOULAGES, François: La estética de la fotografía. Buenos Aires, La Marca Editora, $2010,85-87$.

9. Barthes analiza el contenido del mensaje fotográfico como un análogo perfecto de la realidad. BARTHES, Roland: Lo obvio y lo obtuso. Barcelona, Buenos Aires, México, Paidós Comunicación, 1986, 13-17. 


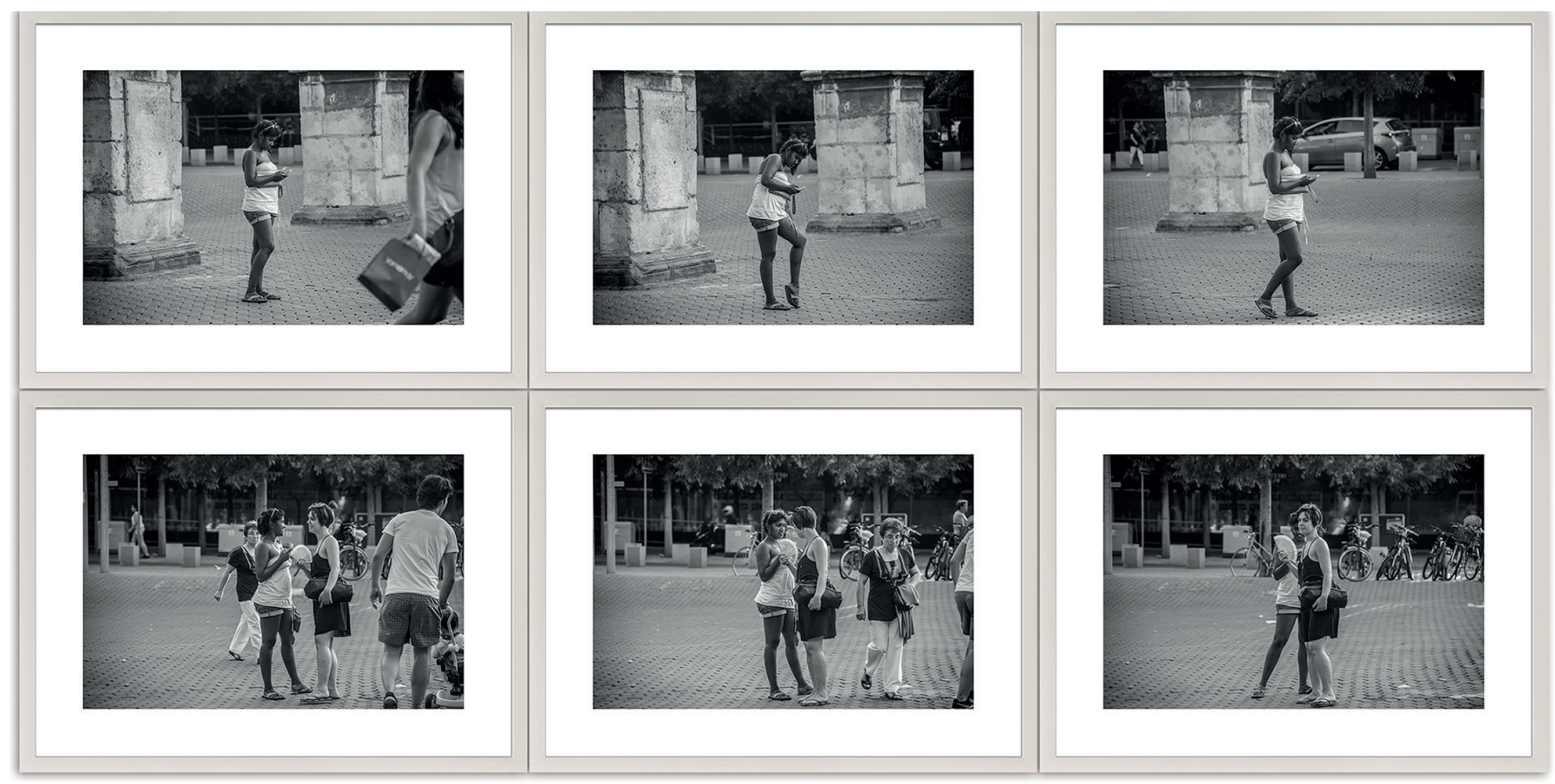

FIGURA 4. AFFIDAMENTO (FRAGMENTO).

conector electrónico o teléfono móvil a la conexión empírica, es decir, al encuentro de dos personas que se dan cita. Este juego de conexiones, de enlaces, funciona como una alianza y también como un concierto. Literalmente se concierta una cita y ésta se establece y, por tanto, se culmina cuando pasamos del lenguaje escrito del mensaje, el pictograma o el emoticón, al parlamento. Es una conversión en el proceso de la conversación. Un lapso que establece diferentes vínculos con el lenguaje y, por tanto, con sus signos. En la primera foto, la que inicia la serie, aparece una mujer estática, en fase de espera. Su aparente inacción formal queda, sin embargo, desmantelada desde el momento en que envía un mensaje electrónico. Ese pequeño emprendimiento genera un campo no colapsado de acontecimientos. Más cuando advertimos que su «microacción», su correspondencia, es un inicio de convocatoria, de comunicación, por tanto, de movilización. La persona contactada parte al encuentro de la confrontación dando por validada la cita. Hay que añadir que en esta serie, por medio de aquello que encuadra, que entra en el campo de acción asignado, se da aleatoriamente la misma acción por duplicado. La cita, la concertación del encuentro da lugar a otra cita y a otro encuentro. Tal y como si se entrara en un posible bucle de aciertos donde el final no sería otro que el triunfo de la comunicación. Todo y todos se relacionan, se establecen en concurrencia como si fueran hipertextos.

La comunicación es un enlace entre dos puntos a través de los medios. El origen de este escrito y de este proyecto analiza la capacidad de movimiento, de traslado del mensaje electrónico como participante del encuentro empírico. La fotografía es el medio de representación de estas narrativas de encuentro, de este sucederse desde la espera hasta el conocimiento. Las narrativas se establecen desde la aleatoriedad 
y lo casual y la función es buscar personajes que establezcan enlaces, conexiones. Todos los sujetos que aparecen en estas series son protagonistas pero todos son incógnitos, desconocidos, salvo en el hecho reproducible de lo fotográfico, de lo representacional. Elegidos por su necesidad de encuentro, por su movilización en un desarrollo de acontecimientos, cuyo fin último es la cita y la participación. Puesto que la cita implica, una vez acordada y una vez iniciada, la comunicación. La espera de algo o de alguien conlleva un tiempo expectante hacia lo que ha de llegar. Supone una soledad, habitualmente transitoria y corta, y un encuentro con aquél que enlaza en ese momento con el hecho inobjetable de la comunicación oral y visual. Lo apasionante en estas series fotográficas es que en el campo de acción desde donde opera una persona a la espera, es decir, desde un encuadre, entran otros objetivos, otros sujetos operantes que inician un juego de veleidades y casualidades que capta y congela el acto fotográfico y que es imperceptible para los sujetos interrelacionados, encuadrados y capturados. Se pone de manifiesto, por tanto, que el juego relacional es sólo permitido al observador de estas imágenes, pero no es observado o apercibido por los sujetos que, en realidad, sí interaccionan en el campo semántico de lo fotográfico y en el campo expandido del territorio empírico. Apasiona, de esta forma, precisamente, ese desapercibimiento de los sujetos entre sí que viene a demostrar la necesidad de reforzar nuestra identidad al ocluirnos, encerrarnos y protegernos de una realidad que es imposible de almacenar, de codificar, puesto que se caería fascinado ante la totalidad de cuanto nos rodea. El mundo es, de esta manera, un conjunto de circunstancias constatables no observadas y la fotografía es el medio que muestra el movimiento continuo de la historia y sus accidentes.

\section{ENTRE PLANOS}

«De pronto el orden se invertía, ellos estaban vivos, moviéndose, decidían y eran decididos, iban a su futuro; y yo de este lado, prisionero de otro tiempo, de una habitación de un quinto piso, de no saber quiénes eran esa mujer, y ese hombre y ese niño, de ser nada más que la lente de mi cámara, algo rígido, incapaz de intervención». ${ }^{10}$

Desde lo paradójico, reconocemos el hecho fotográfico como una ficción o quizá como una verdad imprecisa. Dicha imprecisión es consustancial al propio acontecimiento fotografiado y responde al lugar que ocupa la anécdota en la segmentación de planos de la imagen. Ocurre que, a veces, esa circunstancia casual que aparece en planos secundarios o terciarios es la que mantiene la relevancia en la fotografía. Alargar la mirada, dirigirla y moverla para extenderla allí donde el detalle pasa desapercibido es, en cierto modo, convertir lo fotográfico, lo mirado y no observado en acontecimiento y la anécdota en suceso; es, en definitiva, dotar de movimiento a la imagen. Cuando esto ocurre dicha imagen deja de ser mimética para alcanzar su diégesis.

10. Cortázar, Julio: «Las babas del diablo», en Las armas secretas. Madrid, Cátedra, 1999. 
Moverse entre planos, ampliar la mirada, dar presencia a lo inobservado y construir un juego relacional con los sujetos en escena son algunas de las capacidades del dispositivo fotográfico. Estas capacidades fueron el leitmotiv del guión de la película de Michelangelo Antonioni titulada Blow up, estrenada en I966. Un film basado en el relato de Julio Cortázar titulado Las babas del diablo, editado en I958. El cuento de Cortázar transcurre en París y relata cómo un traductor de origen franco-chileno, Roberto Michel, aficionado a la fotografía, captura el beso de una mujer a un adolescente en lo que aparentemente parece una situación «robada». De manera que cuando el fotógrafo revela el carrete advierte un cambio, una alteración en el recuerdo de la propia escena. Advierte que esa mirada casual a la escena era imprecisa e incompleta dado que la imagen revela la presencia de nuevos personajes.

La película, considerada como una adaptación del relato, acentúa el valor de lo fotográfico como dispositivo capaz de dar a la mirada otra extensión y prorrogarla, no sólo en el espacio sino también en el tiempo. El film narra cómo un fotógrafo de moda londinense, decidido a capturar imágenes de los alrededores de la ciudad, recoge instantáneas furtivas de una pareja conversando. La protagonista en desacuerdo con las imágenes robadas que atentan contra su privacidad, le reclama el carrete. El fotógrafo y flâneur descubre, al ampliar y revelar las fotografías, algo inobservado que había escapado a la mirada y encuadre primeros. En el proceso de revelado de una de las fotografías aparece, sorpresivamente, un hecho oculto y alejado del primer plano: la imagen borrosa de un cadáver. Mediante sucesivos acercamientos o ampliados de la imagen, el fotógrafo confirma que ese elemento inobservado ha sido el escenario de una muerte. El momento furtivo, el instante de gracia y la mirada indiscreta quedaban, de este modo, subvertidos por el nuevo orden, más profundo y complejo: el orden de lo inobservado.

Por un lado, la fotografía captura el acontecimiento y registra lo real-literal. En este sentido, la imagen es entendida como análogo perfecto de la realidad, es decir, un mensaje sin código, en palabras de Barthes, dado que entre el objeto y su imagen no hay traslado sino adecuación. ${ }^{\text {II }}$ Por el contrario, la imagen fotográfica puede ser fantasía, un juego que busca el equívoco de reducir lo real a la bidimensionalidad estableciendo otros posibles órdenes. Es aquí donde se podría retomar la idea del encuadre como estructurador de realidades subjetivas, de planteamientos técnicos para seccionar la contextualidad; pero también de planteamientos simbólicos para la fragmentación de los humores, que es donde se encuentra la visión proyectada entre la panorámica y el acercamiento focal. Encuadrar es poner un marco de subjetividades a un encuentro con la realidad; es definir un espacio, un territorio de intervención sobre el que se establece la pulsión escópica de Lacan. El encuadre junto a la mirada formulan una visión engañosa del espejo: aquel que creímos mirar, que pensamos que nos reflejaría con fidelidad y armonía. Pero ese espejo es dueño de la miniatura, del apercibimiento y la espectacularidad de lo espectral, en tanto, aparece sin ser previamente cotejado en el disparo, en el acto fotográfico. Si finalmente en toda instantánea hay un proceso inicial de intelección, lo hay

11. BARTHES, Roland: Lo obvio y ... 12-14. 
también de vislumbre, de averiguación posterior. Esto significa que es un medio que trasciende y discierne y que aquello que es entrevisto es sólo constatado en el positivado o en la impresión. Sería interesante, de este modo, analizar los paralelismos conceptuales en la lectura de las diferentes series presentadas a partir del encuadre como organizador del recorrido de la mirada. De igual forma, sería pertinente plantear la reorganización de los planos de lectura de dichas imágenes con la intención de que éstos permitan «movimientos» abiertos, capaces de generar una polisemia interesada e ideológica.

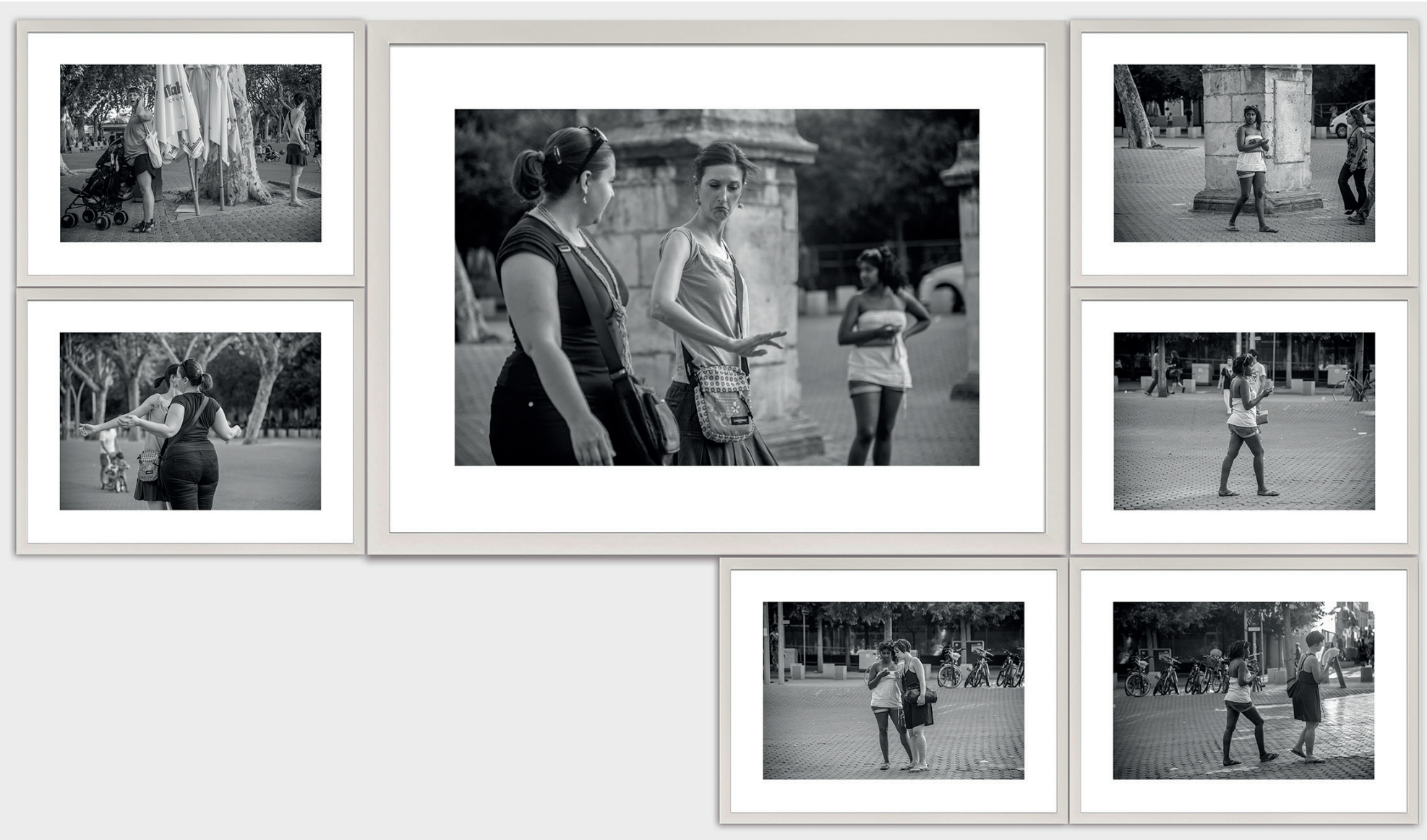

FIGURA 5. AFFIDAMENTO (FRAGMENTO).

Por ejemplo, el cuestionamiento de la estructura representacional convertirá, en la serie Affidamento, la sintaxis en una prevalencia de la mirada. El acontecimiento, es decir, la cita que tendrá lugar es, en un primer momento, un asunto trivial que adquiere relevancia en el encuentro con el «momento decisivo» del disparo. Desde esa certeza, las fotografías nos dirigen al interior de otro flujo de imágenes que muestran tantas realidades como encuentros coincidentes en la misma escena, aunque no en el mismo plano. Por ejemplo, la sintaxis como elemento estructurador de la mirada organiza la gramática representacional de una serie de fotografías en blanco y negro de Louise Lawler, tomadas entre 1970 y I980 y tituladas An 
arrangement of pictures. Lawler aborda en estas fotografías el relato histórico acerca del museo como productor de ideologías y promotor del valor universal del arte como institución. La artista llama la atención sobre los modos y tácticas con las que dichas mediaciones ordenan, distribuyen, muestran y organizan la visibilidad de las obras de arte y cómo éstas generan lecturas que promueven fantasías de orden masculinista. Una de las imágenes, titulada Statue before painting. Perseus with the head of Medusa by Canova (1982), nos ofrece un juego sugerente para la mirada desde un contrapicado que recoge, en el margen derecho del primer plano, la mitad de un desnudo neoclásico, una estatua de mármol de Antonio Canova. Dicha estatua representa una figura de hombre encima de un pedestal. Desde esa angulación, Lawler captura, en primer plano, el falo y el pedestal de la estatua en una posición dominante en relación con el espectador. Los planos secundarios y terciarios fugan en un espacio iluminado, una prolongación de la mirada, una ampliación del punto central de la fotografía que abre paso a la gran galería de las pinturas clásicas del Metropolitan Museum de Nueva York con el cuadro de Giovanni Battista Tiepolo El triunfo de Marius (I729). Lawler nos ofrece, de este modo, una imagen fotográfica estructurada desde un nuevo orden de la mirada. Traza un recorrido visual de carácter crítico en el que establece relaciones entre las obras, los modos de mostrarlas y los espacios, dejando ver la lógica dominante que envuelve al museo como productor de significado y mediador cultural. Pero fundamentalmente con su (des) encuadre amplifica el movimiento de la imagen, a la vez que traslada al espectador a participar de esas contra-lecturas que posicionan a la artista críticamente frente a las jerarquías estéticas y sexuales de los espacios museísticos. Su fotografía es, pues, como la obra Affidamento, la constatación de una cita, la conformación de una movilidad que se genera por un desplazamiento, un desencuadramiento que posibilita el encuentro de algo que le es dado desde la «irregularidad». Affidamento, entendido como «sororidad», es decir, como término que designa prácticas de cooperación y solidaridad entre las mujeres. En el ámbito feminista de la libreria delle donne de Milán el «affidamento» hace referencia al deseo de estructurar relaciones de confianza entre mujeres adultas. En las fotografías que se muestran, las mujeres establecen vínculos relacionales y comunicativos que dibujan una red de posibles encuentros.

En la serie La imagen negada se aprecia, incrustada en la secuencia de un grupo de tres personas en movimiento que aparentan dirigirse a algún emplazamiento, una mancha blanca que la parasita. Inquietante espacio blanco que parece indicar que se puede extender viralmente hasta anular la composición y, finalmente, negar la imagen (La imagen negada). El blanco niega la información, en este caso, parece negar la comunicación, paraliza el movimiento. Parece, de hecho, que ese blanco geométrico que nubla la imagen, que la eclipsa, podría señalar que las lecturas son tantas como la sugestión de lo visto permita predecir. Que, incluso, si apareciese sólo un hilo contextual tras el blanco iniciático, podríamos siempre intuir un inicio 

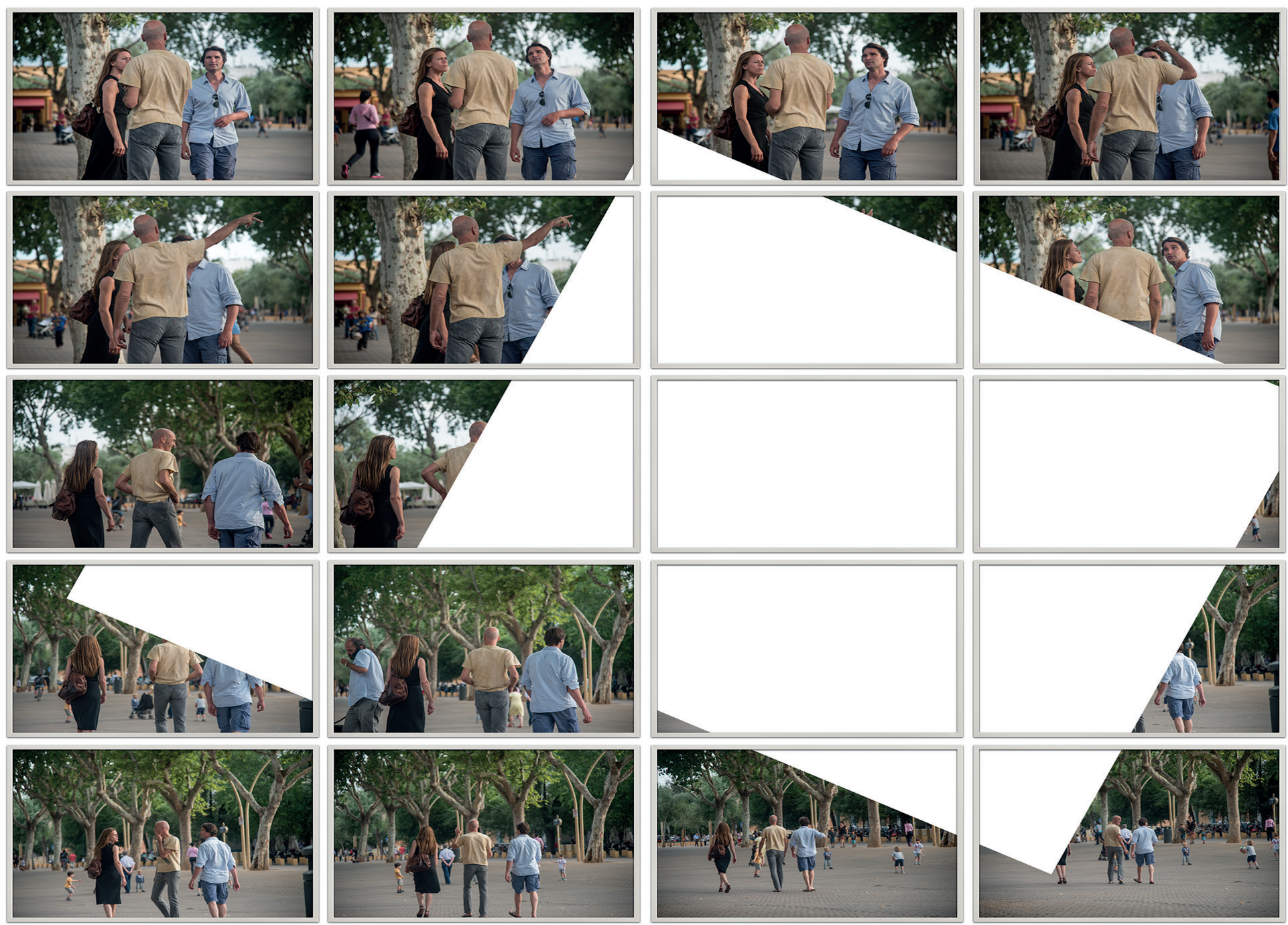

FIGURA 6. LA IMAGEN NEGADA, 20 IMÁGENES DE 26,7 X 40 CM. (C) margarciaranedo.

de narrativa, una nueva «tesis de filosofía de la historia». ${ }^{12}$ Un nuevo ejemplo de traducción sin apoyo crítico, pero con un curso de imágenes numeradas que traslada a un desenlace que nunca tiene lugar salvo en nuestra capacidad no retentiva sino inventiva. Nada es lo que parece ser o todo es exactamente igual a lo que creemos ver. Tras el proceso de lo velado (el espacio blanco) sucede lo revelado (el espacio simbólico). Lo blanco es siempre marginal en su sentido radical, y es límite o extremo de un lugar. Lo blanco también es liminal, es el principio de la narración, es el

12. Benjamin considera que la historia no es continua ni homogénea ni responde a etapas concatenadas sino que es fragmentada y discontinua, tampoco sigue una única dirección dado que se reescribe desde la suma de múltiples instantes diversos y yuxtapuestos marcados por la experiencia individual y la tradición heredada. Un pasado que al mismo tiempo es interpretado en su encuentro con el presente. BENJAMIN, Walter: «Tesis de filosofía de la historia», Discursos interrumpidos I. Madrid, Taurus, 1989. 
espacio para la sucesión de acontecimientos y señales que, casi siempre, cumplen un objetivo de operatividad. El blanco es el inicio, el punto cero de la creación, también su expresión máxima de limpieza y significado. De esta forma, la serie Posiciones se estructura en torno a este margen blanco, a este extremo, a esta limpieza de efectos para intervenir en los contenidos, para crear lazos y distancias entre una pareja que, en todo momento, muestra ser un único cuerpo significante, asociado y disociado por unidades de blanco descompuestas. La pareja modifica su posición continuamente respecto al encuadre inicial. Dicha modificación podría ser interpretada como un hecho arbitrario, dado que en principio se trata simplemente de un recorrido espacial de un hombre y una mujer que se desplazan. Este desplazamiento de las figuras hacia los márgenes del papel los sitúa conceptualmente como sujetos «objetivamente condicionados» por su propio deambular vital.

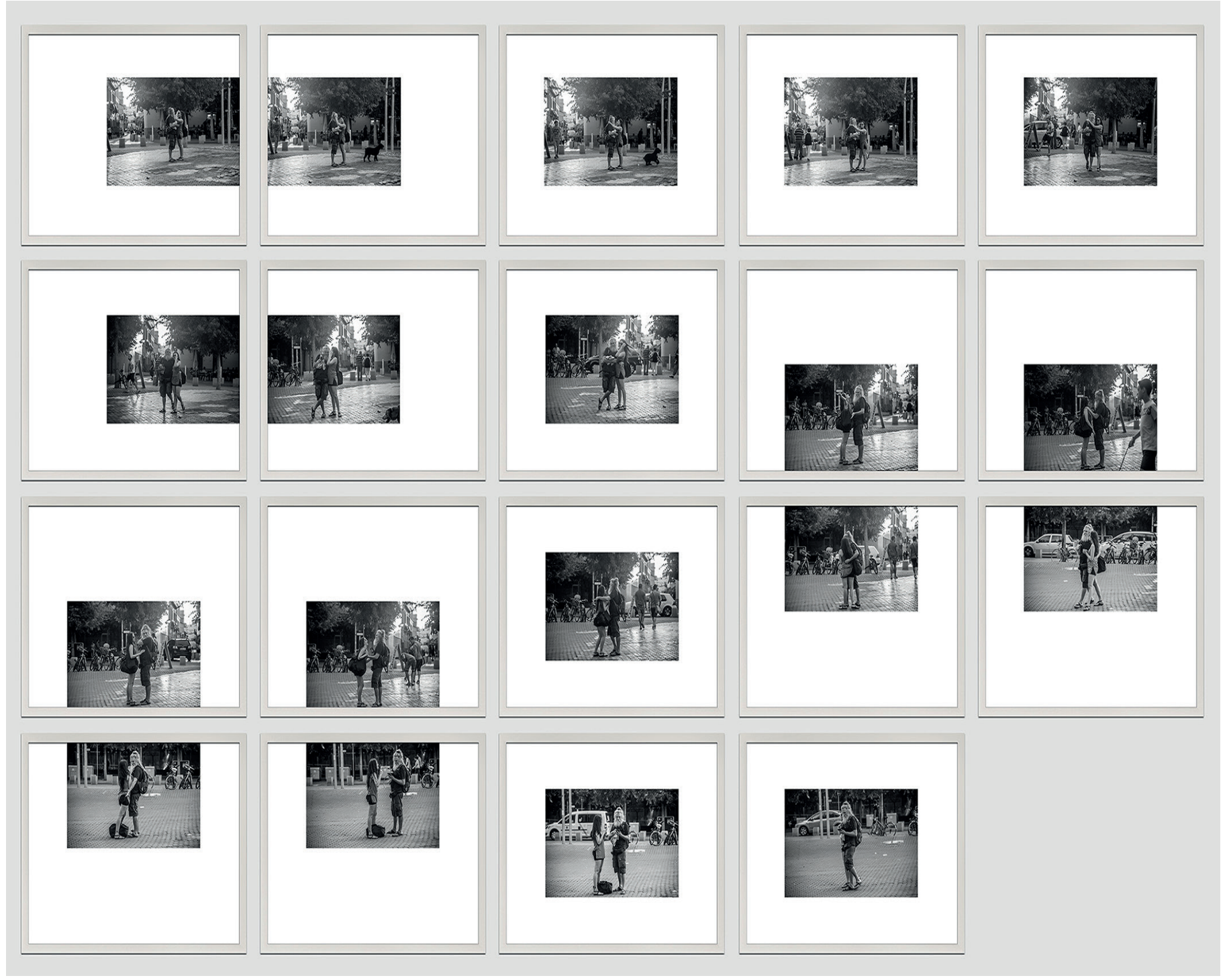

FIGURA 7. POSICIONES, 19 IMÁGENES DE 40 × 50 CM. (C) margarciaranedo. 


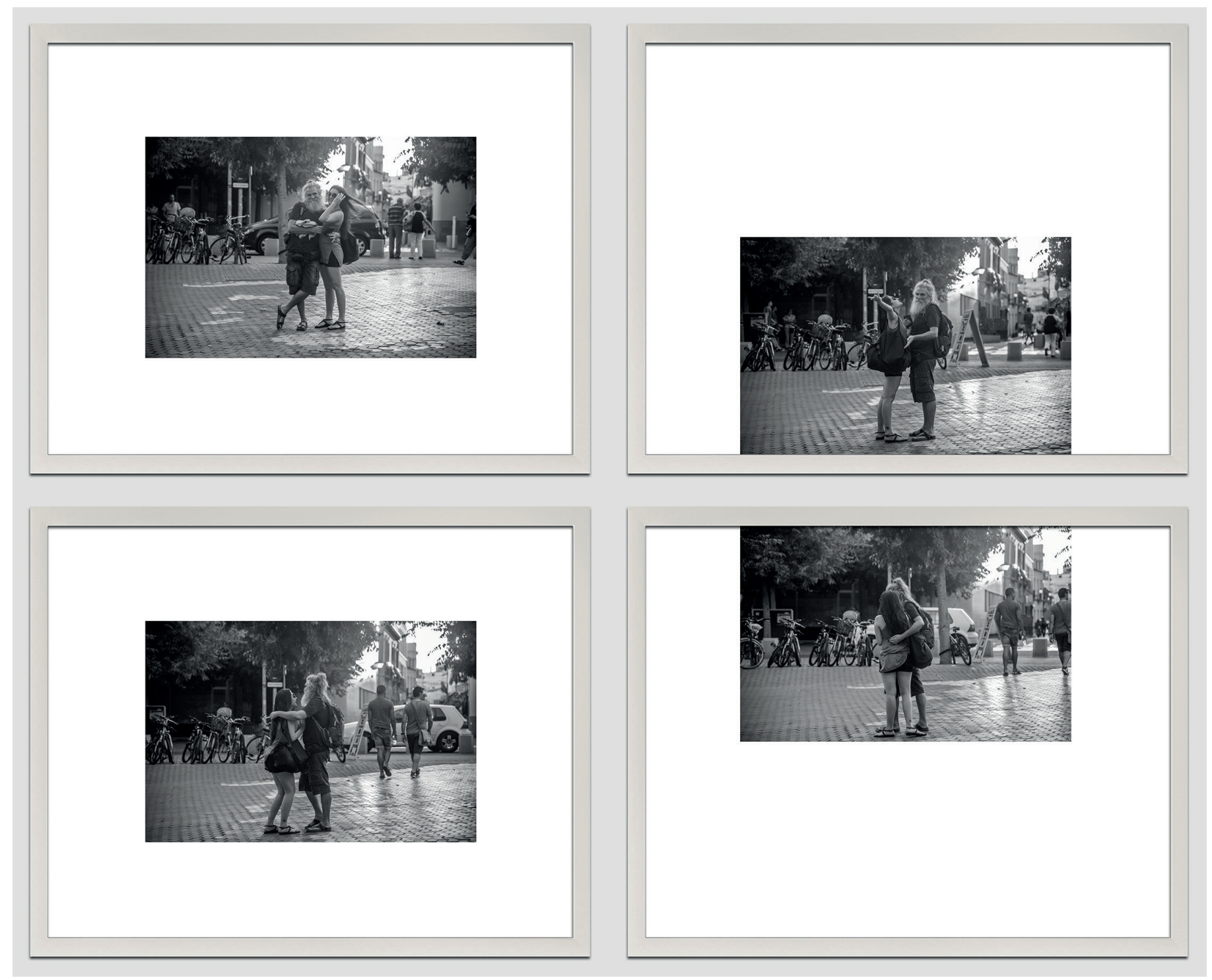

FIGURA 8. POSICIONES, FRAGMENTO. (C) margarciaranedo.

\section{VIDA Y MUERTE DEL PELO}

«Con cada ojeada el dibujo recoge una pequeña prueba, pero este consiste en la reunión de las pruebas aportadas por muchas ojeadas. Por un lado, no hay una visión en la naturaleza tan inalterable como la que ofrecen un dibujo o una pintura. Por el otro, la inalterabilidad de un dibujo está formada por la unión de tantos instantes que pasa a constituir una totalidad más que un fragmento. La imagen estática de un dibujo o una pintura es el resultado de la oposición de dos procesos dinámicos». ${ }^{13}$

13. Berger, John: Sobre el dibujo. Barcelona, Gustavo Gili, 2011, 57. 
Este apartado articula una sintaxis de la representación que narra «la trayectoria del pelo», es decir, un tipo de desplazamiento desde el empleo del dibujo. De esta manera, la suma de todos los pelos dibujados genera una «migración» óptica a través de la cual pensamos en la vida, muerte, caída y posado del pelo sobre el papel. En dicha estructura sintáctica los pelos se alinean como palabras en una frase o como inscripciones jeroglíficas; el resultado emula un modo de escritura. Así, el dibujo estático se convierte en elemento dinámico. En ese traslado participan conceptos como la repetición, la yuxtaposición y la variación para conseguir una dimensión rítmica del dibujo a través de secuencias. Todos estos fragmentos pictográficos podrían considerarse como una marca de vida (la vida y muerte del pelo) o una escritura de la memoria dado que son «marcas» visibles, pero indecibles, que sugieren una escritura de lo subjetivo. A su vez, como señala Mieke Bal, desde «un análisis que no invoque los conceptos semióticos para definir, sino precisamente para superar definiciones delimitadoras», se plantea interpretar el dibujo, en tanto género visual, como una estructura de significación capaz de aludir alegóricamente a la escritura. Que simbólicamente haga referencia al pelo, al mismo tiempo que gráficamente al gesto. Todo ello, participado por la secuencialidad y la serialidad, debería introducirnos en el movimiento. ${ }^{I 4}$
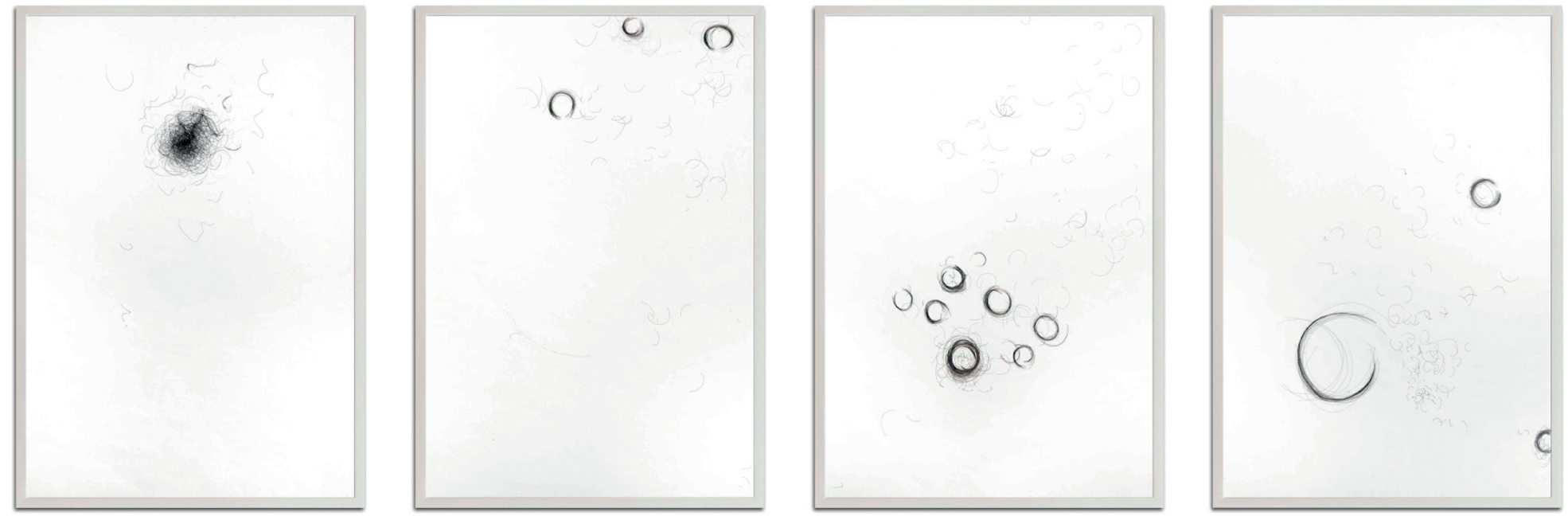

FIGURA 9. (DETALLE) 4 CAPILOGRAFÍAS DE LA SERIE CORRESPONDENCIAS. (C) margarciaranedo.

Una vez que la producción artística transciende su valor moderno y se inscribe en diferentes registros discursivos como la literatura, la filosofía, la antropología, la sociología, la lingüística o el psicoanálisis, comienza su desafío con la escritura.

14. En esta propuesta de establecer una poética del pelo a través del dibujo para configurar una suerte de escritura de lo subjetivo es importante advertir lo que Mieke Bal señala en referencia a cómo pensar la poética visual. Para esta autora es necesario tomar las definiciones y las limitaciones como punto de partida. $O$, en su lugar, tomar como punto de partida la frontera que separa las elocuciones visuales de las lingüísticas, de este modo no se coartarían las posibles interpretaciones. BAL, Mieke: Conceptos viajeros en las humanidades. Murcia, Cendeac, $2009,72$. 
De esta forma, compite por el afán y compromiso de ésta por el relato. La imagen pasa a ser estudiada bajo una consigna semiótica y consecuentemente a ser entendida como estructura de comunicación. Quizá, de esta manera, emprende su competencia con ese otro instrumento común, universal e irremplazable: el lenguaje escrito. Husserl decía «que la escritura era la única que podía darle a esos objetos ideales su idealidad final, que era la única que, de alguna forma, les permitiría entrar en la historia». ${ }^{15}$ Por tanto, «¿Cuál es la primera función del lenguaje: producir un pensamiento o comunicarlo?» ${ }^{16}$

El dibujo es una marca que establece límites y provoca mediciones. Dibujar es una acción que implica una intimidad con el cuerpo; es establecer relaciones escénicas con el espacio tanto real y físico como con la psique. Para Freud el aparato psíquico es ilimitadamente receptivo a cualquier percepción nueva y además es capaz de registrar todo a modo de huellas mnémicas, por eso la memoria es la clave de todo proceder psíquico. El dibujo entendido como pensamiento abstracto provoca una lectura freudiana. El sueño, al igual que el pensamiento, lo indecible, el delirio o lo inexplicable, es considerado por Freud como un sistema descifrable, como una máquina de escritura con reglas semejantes a las de los jeroglíficos. Freud hace una curiosa analogía entre el aparato psíquico y un juguete infantil, una pizarra sobre la que se puede escribir, trazar y dibujar con una tiza y borrar reiteradamente y que, sin embargo, conserva la memoria de todo lo borrado. De modo que la psique guarda de forma ilimitada, como si se tratase de un gran archivo en el que almacenar cualquier recuerdo aunque éste haya sido eliminado. ${ }^{17}$ El pelo caído sobre la mesa insinúa, con su forma y su clara linealidad, el inicio de un lenguaje pues es la primera fuente desde donde establecer un código, el establecimiento de caracteres que se conforman por adición. La suma de pelos nos traslada a formas, sin duda, pero también configura una caligrafía aborigen, un ciclo de iniciación para una construcción de significados poliédricos. Estas caligrafías bien pudieran llamarse Capilografías, pues a partir de una deyección, del abandono de un origen, la cabeza o la cabellera, se manifiestan autónomas y plenas de significado. Hablamos siempre del pelo que como en la escritura se posa sobre un material que es la hoja en blanco: el inicio de la poiesis, de la creación. En su caída, el pelo describe un movimiento y genera conexiones con el espacio que lo envuelve hasta establecerse como huella sobre la superficie del papel. Es el rastro que segmenta, incide o dibuja sobre el blanco, donde se proyecta, desde la sucesión de marcas.

Capilografías retoma el gesto de las primeras grafías para establecer dibujos que se resuelven con la morfología propia del pelo. Estos «caracteres» o registros gestuales emulan un modo de escritura a la vez que transcriben una de las infinitas posibilidades de existir, de provocar una determinada forma generada por el movimiento y el descenso. Son la idealización del lenguaje o la conceptualización de la palabra escrita. El dibujo, en este sentido, es la materialización del pensamiento

15. Derrida critica la fenomenología de Husserl y señala como equívoca y oscura su observación sobre la escritura. DerRIDA, Jacques: ¡Palabra! Madrid, Editorial Trotta, 2001, 20-21.

16. KRISTEVA, Julia: El lenguaje, ese desconocido. Madrid, Editorial Fundamentos, 1988, 10-12.

17. DerRIDA, Jacques: La escritura y la diferencia. Barcelona, Editorial Anthropos, 2012, 271-273. 


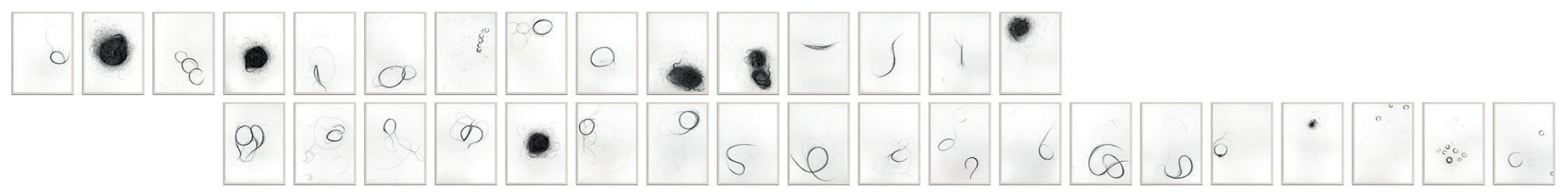

FIGURA 1O. CORRESPONDENCIAS, 35 (DIBUJOS) CAPILOGRAFÍAS DE 25,5 × 36,5 CM. TINTA CHINA SOBRE PAPEL DE ALGODÓN.

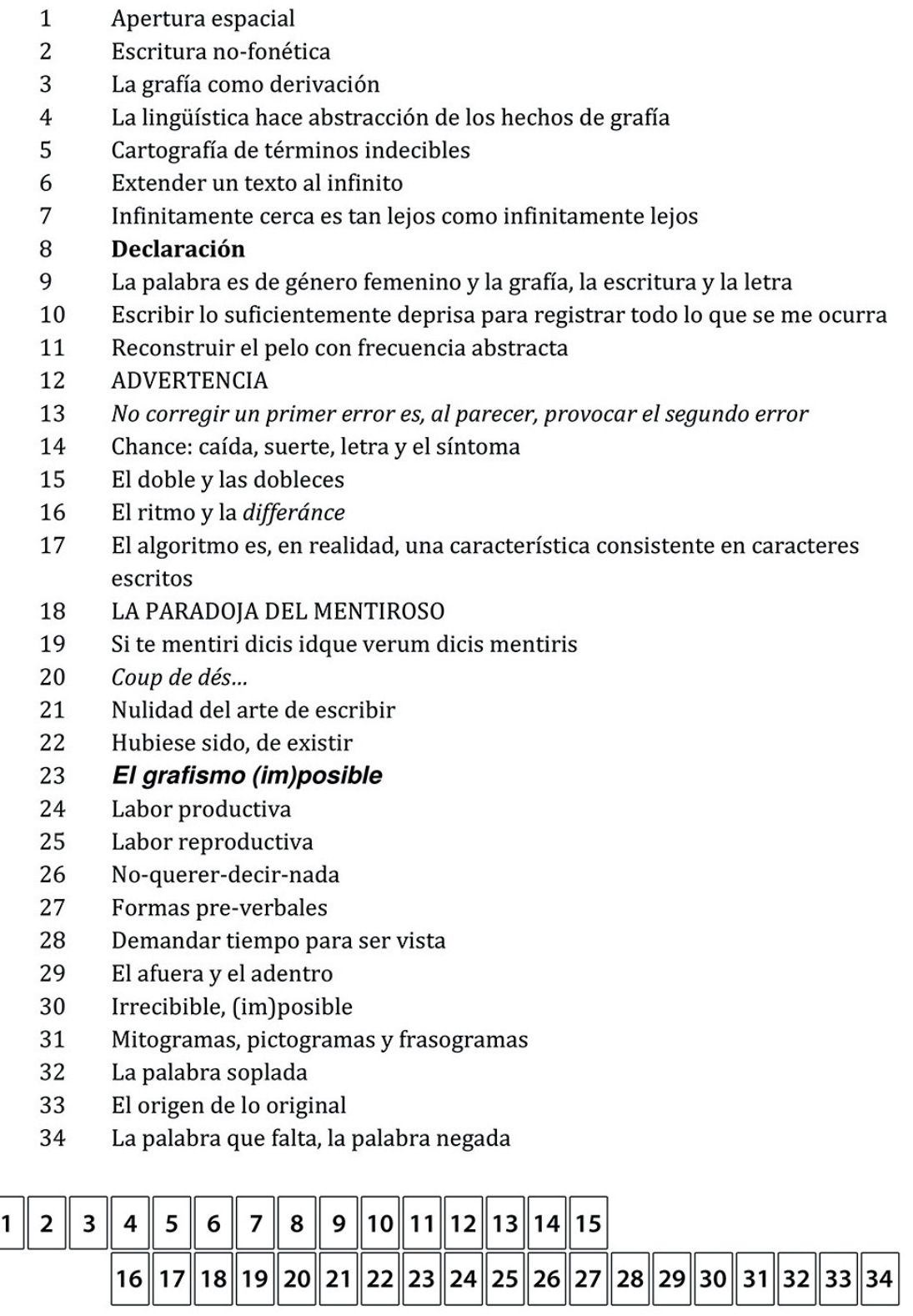


libre no descifrable. Estas series persiguen trazar mediante el dibujo realista del pelo una poética que ponga en pie una estructura comunicativa abierta y capaz de contener un cuerpo plural de significados. El pelo, en realidad, parece buscar el fundamento, el dibujo del pelo el significante y el resultado visual el espacio limitado por el papel donde se dan todos los significados posibles, todas las alternativas interpretativas que pudieran ser resueltas. Quizá con tales pretensiones para el pelo se deba hacer uso de ciertos formulismos teóricos que sostengan vínculos de coherencia y estructura. Como el hecho de hacer referencia al concepto de «obra abierta» de Umberto Eco para analizar algunas teorías en torno a la representación y su capacidad comunicativa desde registros entendidos como no discursivos, tales como el dibujo ${ }^{18}$. Alusión que también evoca que la obra se justifique como una estructura desordenada capaz de provocar lo indeterminado, ambiguo, probable y plurivalente. De manera que el pelo se convierta en trazo, el trazo se interprete como signo, el signo se justifique como código y, de este modo, se establezcan combinaciones y algoritmos. Al mismo tiempo que se propician múltiples lecturas $\mathrm{y}$ variadas interpretaciones.

Existe la posibilidad de introducir la escritura como pictograma; pero en un grado inicial, abocetado, lo necesario para preservar la escritura o, en su lugar, el gesto que nos traslada a ella. La aparición de la escritura no es fortuita, es la evolución de las primeras representaciones mitográficas como los pictogramas o ideogramas. Aunque la realidad es que en la actualidad no hay consenso acerca de si se originó como lenguaje vocálico o bien como grafismo. Lo cierto es que muchas de estas escrituras preliminares, como las de las antiguas dinastías chinas, imitaban el lenguaje gestual; por esta razón, algunos investigadores consideran que dichas grafías son anteriores al lenguaje fonético. El objeto no era representado sino designado por el dibujo del gesto. Si miramos hacia atrás observaremos como la humanidad ha ido elaborando diversos tipos de escritura a lo largo del tiempo. Asumimos que el lenguaje escrito, es decir, el lenguaje gráfico, aparece antes que el fonético. En sentido freudiano, «la letra, lo que está recubierto (vuelto inconsciente), sería la escritura que ocurre dentro y antes del habla» ${ }^{19}$. Lo escrito sería, por tanto, envoltorio, revestimiento, intención enmascarada; la escritura, a su vez, indicaría la acción dado que actúa como fijación controlada del propósito o idea en un espacio blanco que es el papel. La escritura es, por consiguiente, el dibujo, la marca, la representación gráfica del habla.

La serie Correspondencias, desde el dibujo y la escritura, revisita el espacio de inmanencia donde se inscriben todos esos giros y «rodeos» en la gramática de la lengua y la escritura, a la manera del propio Baudelaire, Derrida y Mallarmé (quien acabó por convertirse en el autor anónimo de sus propias obras) o, finalmente, Flaubert quien pensó en escribir un libro sobre nada, un libro que sólo apareciese como pura forma.

18. Eco, Umberto: Obra abierta. Barcelona, Editorial Planeta, 1992.

19. Philippe Sollers, en «Un paseo sobre la luna», una introducción a De la gramatología, analiza cómo la metafísica occidental impone un modelo de dominación etnocéntrica al margen del inconsciente freudiano. DERRIDA, Jacques: De la gramatología. México, Buenos Aires, Madrid, Siglo XXI Editores, 2012. 


\section{CAPILOGRAFÍAS}

«Conectó la TV. Un Predicador predicaba con un lenguaje de signos para sordomudos. Se fijó en que el signo que significaba «Jesús» consistía en golpear alternativamente las palmas de una y otra mano con el dedo corazón, denotando los clavos de la crucifixión. Bajó el volumen y estuvo fijándose en las manos del Predicador. Tuvo la sensación de que el lenguaje saltaba al interior de la habitación». ${ }^{20}$

Las Capilografías, o las formas visuales de los dibujos del pelo, proponen la opción de una grafía, de un simulacro de la palabra, de lo audible, de «el grado cero de la escritura», de manera que dicha ficción carezca de la posibilidad de «decirlo todo» y de paso articule una suerte de posibles ideas. Derrida nos advierte del etnocentrismo que siempre ha acusado el concepto de escritura. Por eso entiende que su historia, desde una narrativa occidental, es interesada al no querer cuestionar las condiciones de su representación. En este sentido, considera importante el descentramiento de otras escrituras no-occidentales que se alejen de esa linealidad histórica. Probablemente, lamentara el fracaso de la idea imaginada por Leibniz en el siglo XVIIl y conocida como "pasigrafía», concepto que define una escritura o lengua universal bajo la que toda propuesta pueda ser leída desde una lógica matemática y en la que los caracteres y reglas permitiesen debatir cualquier desacuerdo y resolverse a través del cálculo matemático. ${ }^{21}$ La pasigrafía, quizá, podamos hoy reinterpretarla como esa «aventura seminal» de la escritura «pre-literal», una especie de suerte de pensamiento de la grafía capaz de retar al propio sistema de enunciar, de decir, de contar. Es, en cierto modo, una pauta de desmantelamiento del código cartesiano con el que le damos forma a la escritura.

En I804, el geógrafo y naturalista Alexander von Humboldt señaló la necesidad de un lenguaje geológico que ayudase a la comprensión precisa de los fenómenos geológicos de forma universal. Para ello introdujo el concepto de «pasigrafía geológica» e ideó unos planos pasigráficos que elaboró con los perfiles verticales de la estratificación de las rocas primitivas cuyas particularidades eran representadas bajo la diferenciación de tres colores: verdinegro, blanco amarillento y rojo. ${ }^{22}$ Esta idea de codificar el lenguaje bajo un sistema de representación gráfico quedó normalizada como un método de ordenación visual al que cualquier persona tendría acceso y podríamos pensar en ella visualmente como la antesala de los actuales gráficos estadísticos.

Esta preocupación por la eficacia de la representación de los sistemas codificados para narrar acontecimientos aparece en proyectos como I' $m$ still alive (20I0), Continuum (2010) o Simbografías (2011). ${ }^{23}$ En dichos trabajos se analiza el empleo del gráfico estadístico y el signo como lenguaje incapaz de informar, de advertir sobre

20. Shepard, Sam: Crónicas de motel. Barcelona, Anagrama, 1989, 33

21. La pasigrafía es un tipo de representación gráfica que busca hacer inteligible un texto a cualquier persona que lo lea (la partícula «pasi» en griego significa para todos) independientemente de la lengua que éste hable. Como ocurre con los números, se basa en escritura de conceptos en vez de palabras y fonemas.

22. Reвок, Sandra: Alexander von Humboldt. Madrid, Fundación Ignacio Larramendi, 2013.

23. En http://www.margarciaranedo.com [11 de abril de 2016] 
el acontecimiento, dado que sólo parecen aderezar el estado de realidad. Cuando dichos gráficos denuncian acontecimientos sociales o hechos relativos al género y muestran datos concernientes a la diferencia, la violencia, los malos tratos, la prostitución, o cualquier otra problemática de exclusión social, parecen estar más sujetos a una relación estrecha y formal con el papel en blanco desde su fruición colorista que a la anestética de sus contenidos de alteridad y desequilibrio. Podríamos decir que la realidad truncada anula cualquier intento de representarla. Quizá, y fundamentalmente en este sentido, el acontecimiento, como sujeto ideológico, compromete el dominio del signo. Así, teniendo en cuenta la ineficacia del gráfico, la palabra escrita para expresar circunstancias extremas puede, igualmente, resultar una abreviación de lo real, dado que suprime cualquier expectativa.

Correspondencias titula a la serie compuesta por treinta y cinco dibujos de pelos, junto a un texto que nomina a cada uno de ellos. El título recuerda al soneto homónimo de Baudelaire incluido en Las flores del mal; sin embargo, en esta serie, es tan sólo un término que conduce a relacionar la palabra escrita y el gesto dibujado. Se establece, de este modo, una correspondencia al consignar cada dibujo con un texto o frase determinada. Dicha complementación o equivalencia entre lenguaje escrito y dibujado pone en pie la controvertida relación entre ambos lenguajes: en el momento que se enuncia algo respecto al dibujo deja de ser el dibujo para pasar a ser aquello que se dice con palabras creando el problema conceptual de la confusión.

La serie, estructurada como un pictograma, organiza los dibujos en una presentación lineal en el espacio de la pared, creando una fila, o varias, a modo de renglones superpuestos. La secuencia de dibujos debe ser leída de izquierda a derecha como si se tratase de un texto. Para comprender en su totalidad la obra el espectador precisa moverse, desplazarse a lo largo de la secuencia. Debe avanzar y retroceder dado que la imagen de partida contiene las frases y palabras que los nominan individualmente. La serie propone de este modo entorpecer la creencia de interpretar como estáticos los modos de lectura de las imágenes. Se acerca, o al menos lo pretende, a la propuesta de Derrida que, bajo el título Glas busca producir lo inaudible y descifrar el lenguaje como una posible puesta en marcha de una nueva figura de la interpretación. ${ }^{24}$ Propone códigos, reglas, normas de escritura más allá del contenido mismo, más allá de lo que comunican. Glas es un intento de representar la producción textual como un modo de combinatoria entre lo reglado y lo azaroso. Es un intento de poner en pie la materialidad del texto, de la letra, para hacer de la escritura una estructura no lingüística. Entrecruza las cuestiones, organiza nuevos procedimientos, formula retóricas de la escritura que pueden llegar a considerarse más atrevidas y desafiantes que el contenido mismo: la grafía como escritura, como derivación. La disposición tipográfica, la colocación textual, la sobreescritura, los injertos, la reordenación, lo heterogéneo del cuerpo escrito de Glas evoca Un coup de dés jamais n'abolira le hasard ${ }^{25}$ La serie Correspondencias es el constructo inaugural y final de la obra en continuo movimiento.

24. DerRIDA, Jacques: Glas. Madrid, Oficina de Arte y Ediciones, 2015.

25. Mallarmé, Stéphane: Un coup de dés jamais n'abolira le hasard. París, Gallimard, Collection Blanche, 1993 

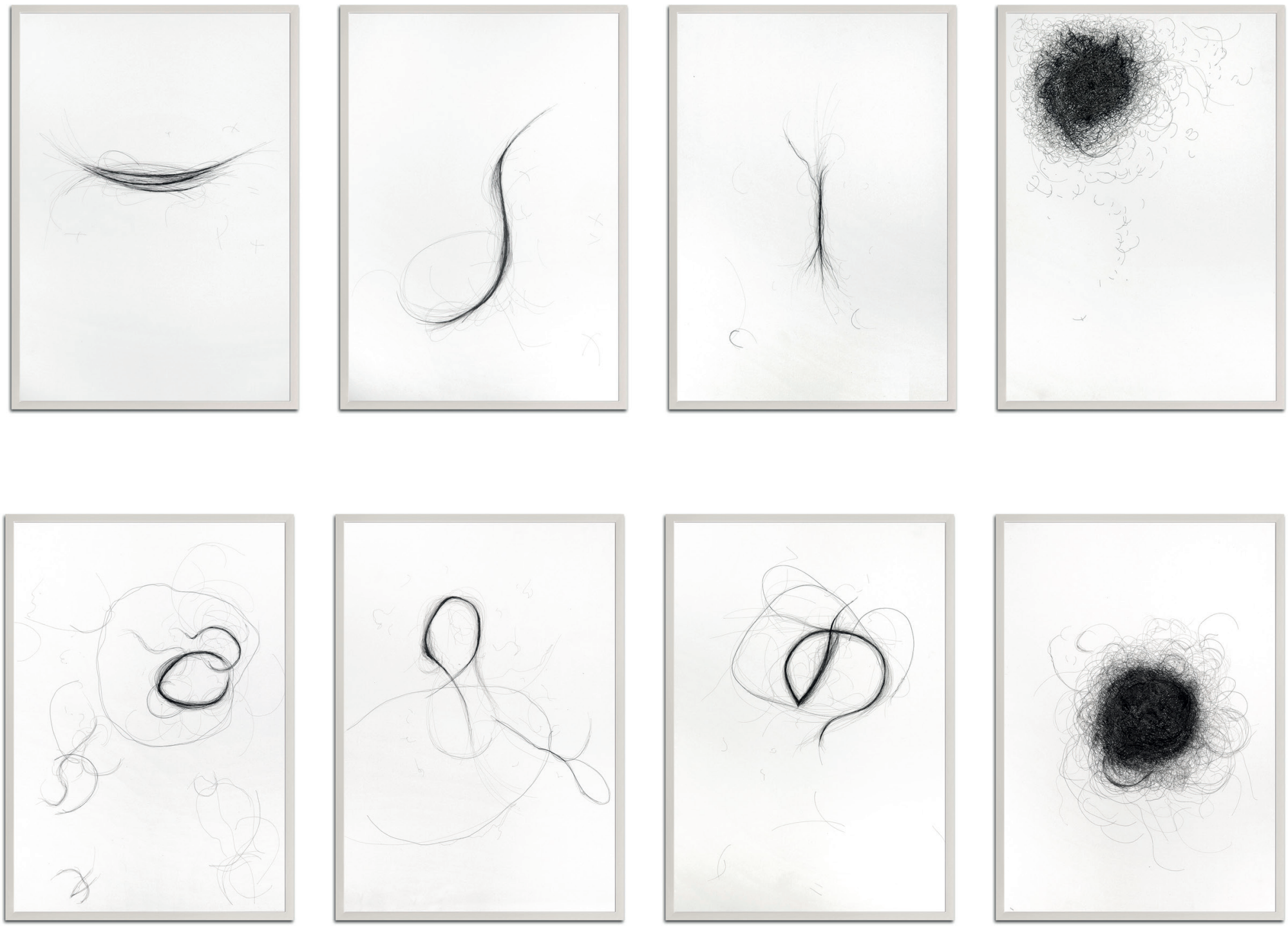

FIGURA 12 Y FIGURA 13. (DETALLE) 8 CAPILOGRAFÍAS DE LA SERIE CORRESPONDENCIAS.

\section{ESTACIÓN: TRÁNSITO}

Con este apartado final se llega a la estación, esto supone un fin de viaje, una estada tras el movimiento o contrariamente el inicio desde el que nos introducimos al movimiento y a la velocidad. Toda estación es un destino entre tránsitos, un punto de llegada o un punto de salida, pero todos los tránsitos implican la parálisis (la estación) y el movimiento.

En definitiva, podríamos decir que las series descritas y analizadas, tanto las fotográficas (Affidamento, La imagen negada y Posiciones) como la dibujística titulada Correspondencias, conjugan en común ideas que tienen que ver con el deseo 
de afianzar lo transitorio o lo efímero. Para ello se ha examinado la estrecha relación que lo fotográfico establece con el movimiento para mostrar un fragmento de vida, de tiempo, es decir, una determinada duración desde dos perspectivas: la del fotógrafo y su seguimiento del objetivo y la del objetivo a través de la cita y el emplazamiento. Esta relación se pone de manifiesto en la pérdida de eventualidad y contingencia de las imágenes fotosecuenciadas puesto que su movilidad refuerza el relato, y conocemos qué acto antecede y precede a la instantánea. Al mismo tiempo, se ha considerado el encuadre fotográfico como un estructurador de las ideas que permite moverse o desplazarse a través de los planos para organizar el discurso desde la propia imagen. Una vez resueltas las imágenes, la distribución y colocación de éstas en la sala de exposición invitan de nuevo al movimiento dado que su lectura (de izquierda a derecha), a base de disposiciones que recuerdan a los jeroglíficos o a los antiguos pictogramas, proyecta un ir y venir continuo.

Por otra parte, el pelo, o el dibujo del pelo, también sugiere un ritmo, una oscilación o desplazamiento, dado que dibujar requiere moverse y, por tanto, establecer relaciones escénicas con el espacio. Pero además los pelos evocan rítmicamente el deslizamiento. La belleza del pelo no sólo se encuentra en su color, forma o cuerpo, se encuentra fundamentalmente en el movimiento, en su cadencia, en su oscilar. La caída, el abandono del pelo de su origen, y el posterior posado en el blanco del papel alejan a éste desprendimiento de lo abyecto, del declive en que se convierte todo desarraigo. El papel blanco significa al pelo yacido, lo subraya, le inquiere ritmo y fogosidad y lo aleja del simbolismo de la muerte. La serie, la suma de todos los dibujos, es el conjunto de muchos ritmos distintos que recuerdan los estados (de relax o tensión) de la propia psique o conciencia. El orden, la dotación de la serie como estructura de sentido es organizada mediante las asociaciones que se encuentran entre el dibujo y el texto o entre el dibujo y la palabra. Cada imagen se argumenta como un fragmento, un instante, una fracción de tiempo que no consigue consolidar nada. Cada imagen refleja el intento de afianzar su forma alegórica. Con ello nos desplazamos por la acción hacia la consecución de una idea o conjunto de ellas. Ideas que no necesariamente son conclusivas y cerradas. Esta inconclusión es la base de su revuelta, de su alzamiento. 


\section{BIBLIOGRAFÍA}

BAL, Mieke: Conceptos viajeros en las humanidades. Murcia, Cendeac, 2009.

BACHELARD, Gastón: La intuición del instante. México, Fondo de Cultura Económica, 1999.

BARThes, Roland: El grado cero de la escritura. México, Buenos Aires, Madrid, Siglo XXI

Editores, 20II.

-: La cámara lúcida. Barcelona, Paidós, 20 o.

—: Lo obvio y lo obtuso. Barcelona, Buenos Aires, México, Paidós Comunicación, I986.

Benjamin, Walter: «Tesis de filosofía de la historia», Discursos interrumpidos I. Madrid, Taurus, 1989 .

Berger, John: Sobre el dibujo. Barcelona, Gustavo Gili, 2oII.

BERGSON, Henri: Introducción a la metafísica y la intuición filosófica. Buenos Aires, Ediciones Siglo Veinte, I966.

BREA, José Luis: Las tres eras de la imagen. Madrid, Akal Estudios Visuales, 20 o.

BUTLER, Judith: Mecanismos psíquicos del poder. Madrid, Ediciones Cátedra, 20oI.

CORTÁZAR, Julio: «Las babas del diablo», Las armas secretas. Madrid, Cátedra, I999.

Deleuze, Gilles: La imagen-movimiento. Barcelona, Buenos Aires, México, Paidós

Comunicación, 2013.

DerRIDA, Jacques: De la gramatología. México, Buenos Aires, Madrid, Siglo XXI Editores, 2012.

-: La escritura y la diferencia. Barcelona. Editorial Anthropos, 2012.

-: Glas. Madrid, Oficina de Arte y Ediciones S.L., 2015.

-: ¡Palabra! Madrid, Editorial Trotta, 200I.

Eco, Umberto: Obra abierta. Barcelona. Editorial Planeta, I992.

HAUSER, Arnold: Historia social de la literatura y del arte. Madrid, Debate, I998.

KRISTEVA, Julia: El lenguaje, ese desconocido. Madrid, Editorial Fundamentos, I988.

MALlaRmÉ, Stéphane: Un coup de dés jamais n'abolira le hasard. París, Gallimard, Collection Blanche, I993.

Rевок, Sandra: Alexander von Humboldt. Madrid, Fundación Ignacio Larramendi, 2013.

Shepard, Sam: Crónicas de motel. Barcelona, Anagrama, I989.

SoulAges, François: La Estética de la fotografía. Buenos Aires, La marca editora, 20 o. 
AÑO 2016

NUEVA ÉPOCA

ISSN: $1130-4715$

E-ISSN 2340-1478

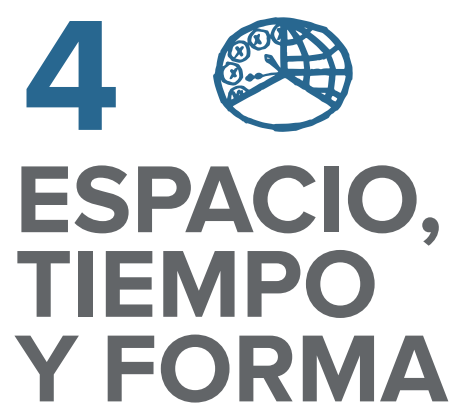

Dossier by Mieke Bal: Art Moves: Performativity in Time, Space and Form / El Arte (Se) Mueve: Performatividad en el Tiempo, el Espacio y la Forma por Mieke Bal

15

MIEKE BAL (GUEST EDITOR)

Movement and the Still Image / El movimiento y la imagen fija

\section{First reflections on movement}

4.5 Miguel Ángel Hernández Navarro

Retorcer el tiempo: Fernando Bryce y el arte de historia / Twisting Time: Fernando Bryce's Art of History

7

NANNA VERHOEFF

Surface Explorations: 3D Moving Images as Cartographies of Time / Exploraciones de superficie: Imágenes 3D en movimiento como cartografías del tiempo

\section{Ramón Salas Lamamié de Clairac}

El tiempo dialéctico: la cuarta era de la imagen / Dialectical Time: The Fourth Era of the Image

17 Mar García RANEdo

Desplazamientos (in)móviles / (Im)mobile Displacements

\section{Technique: «mistakes» as movement}

143 Jose Manuel Garcia Perera

El movimiento como simulacro en el mundo virtual: Michael Betancourt y el arte de la inmediatez / Movement as Simulacrum in the Virtual World: Michael Betancourt and the Art of Immediacy

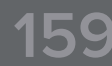

ERNST VAN ALPHEN

Exoticism or the Translation of Cultural Difference / Exotismo o la traducción de la diferencia cultural

\section{Mónica Alonso Riveiro}

Arqueología de la ausencia de Lucila Quieto: un viaje hacia la imagen imposible / Archaeology of Absence of Lucila Quieto: a Trip to the Impossible Image

\section{AYLIN KURYEL}

Disorienting Images: A Bust with Multiple Faces / Imágenes que desorientan: una instalación con múltiples caras
219

AMPARO SERRANO dE HARO

The Movement of Miracles / El movimiento de lo milagroso

Sharing space: discourses of display

235 Elisa de Souza Martínez

Ethnographic Image: In and Out of the Exhibition Space / La imagen etnográfica: dentro y fuera del espacio expositivo

\section{NOA ROEI}

Making National Heritage Move: Ilya Rabinovich's «Museutopia» Projects / Dinamizando el patrimonio nacional: el proyecto «Museutopia» de llya Rabinovich

279 FERNANDO de FELIPE \& IVÁN Gómez

Cronoendoscopias: un viaje alucinante al interior del cuerpo humano / Chronoendoscopies: Imagining a Trip inside the Human Body

\section{Being part of it: affect and the body}

309 JefFrey MANOEL PIJPERS

Affective Resonance: The Moving Potential of Music in Gilberto Gil's «Aquele Abraço» / Resonancia afectiva: el potencial dinámico de la música en «Aquele Abraço» de Gilberto Gil

329

LAIA MANONELLes MONER

Micro-utopías de lo cotidiano, espacios de encuentro en el arte relacional: una aproximación a ciertas acciones de Marina Abramović y Tino Sehgal / Micro Utopias of the Quotidian, Meeting Spaces in Relational Art: An Approach to some Performances of Marina Abramović and Tino Sehgal

351

PATRICIA LIMIDO \& HeRvé Regnaud

Les racines de l'œuvre : puissance émotionnelle et forme artistique. Deux examples de land-art en France / Roots of Art: Emotional Impact and Artistic Form. Two Cases of Land-Art in France

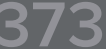

Clara LAguillo

Hibridación de medios en la confluencia de forma, tiempo y espacio: de la Danse Serpentine al Capturing Dance / Hybridization of Artistic Media on the Crossroad of Shape, Time and Space: From Danse Serpentine to Capturing Dance 


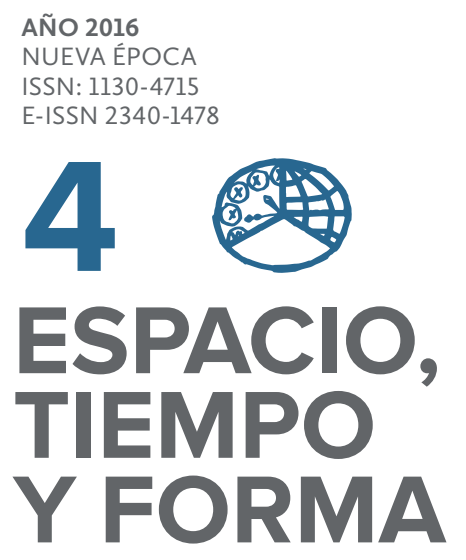

Miscelánea · Miscellany

\section{RaImundo Moreno Blanco}

Aportaciones a la arquitectura y la historia del monasterio del Sancti Spiritus de Ávila / Contributions to the Architecture and History of the Monastery of Sancti Spiritus in Ávila

1.17 José Manuel Almansa Moreno

Estudio y recuperación de la Iglesia de San Lorenzo, Úbeda (Jaén) / Study and Recovery of the Church of San Lorenzo, Úbeda (Jaén)

\section{Manuel Gil Desco}

Imágenes de la locura en la Edad Moderna: escarnio y máscara en el discurso del poder / Images of Madness in the Modern Age: Derision and Mask in the Discourse of the Power

483 Ignacio josé López HeRnández

El Cuerpo de Ingenieros Militares y la Real Junta de Fomento de la isla de Cuba. Obras públicas entre 1832 y 1854 / Spanish Military Engineers and the Real Junta de Fomento at the Island of Cuba. Public Works between 1832 and 1834

\section{9}

\section{NOELIA FERnÁNDEZ GARCíA}

La labor reconstructora de Francisco Somolinos en Langreo, Asturias: La iglesia parroquial de Santiago Apóstol / The Rebuilding Task of Francisco Somolinos in Langreo, Asturias: The Parish Church of Santiago Apostol

\section{Rocío GARRIGa InAREjOS}

Espacio resonantes: del paisaje sonoro de las trincheras a la escucha del silencio en Alfonso Reyes y John Cage / Resonant Spaces: From the Soundscapes of the Trenches to the Hearing of Silence in Alfonso Reyes and John Cage

\section{Reseñas · Book Review}

551 Jose Antonio Vigara Zafra

Vigo Trasanco, Alfredo: La ciudad y la mirada del artista. Visiones desde el Atlántico. Santiago de Compostela, Teófilo, 2014.

555 Jesús Ángel SÁnCHEZ GARCíA

Alonso Pereira, José Ramón (dir.): Modernidad y contemporaneidad en la arquitectura de Galicia. Universidad de La Coruña, La Coruña, 2012.

\section{Joaquín Martínez Pino}

Gimeno, María y Collazos, Raquel (coord.): Paradores de Turismo. La colección artística. Madrid, Paradores de Turismo, Fundación Mapfre, 2015. 